\title{
Cavitation detection for brain imaging and therapy
}

\author{
Meaghan O'Reilly, Ryan Jones, Kullervo Hynynen \\ From Current and Future Applications of Focused Ultrasound 2014. 4th International Symposium \\ Washington, D.C, USA. 12-16 October 2014
}

\section{Background/introduction}

Cavitation-mediated therapies for the brain, such as ultrasound-induced Blood-Brain barrier opening and sonothrombolysis for the treatment of stroke, are being increasingly investigated. Robust methods for monitoring and controlling cavitation are necessary for safe translation of these techniques into clinical practice. This talk will review our work detecting and mapping cavitation activity in the brain, as well as using the cavitation signals to control treatments. The potential application of these techniques for mapping the vasculature will also be discussed.

Submit your next manuscript to BioMed Central and take full advantage of:

- Convenient online submission

- Thorough peer review

- No space constraints or color figure charges

- Immediate publication on acceptance

- Inclusion in PubMed, CAS, Scopus and Google Scholar

- Research which is freely available for redistribution 